active part in helping to establish the vitamin-oil industry in Angola. In 1946 he returned to Johannesburg on his appointment to the staff of the University of the Witwatersrand as senior lecturer in botany.

\section{The Meteorological Research Committee}

November 1962 sees the twenty-first anniversary of the Meteorological Research Committee, set up during the Second World War "to advise the Secretary of State for Air as to the general lines along which meteorological research should be developed". Official meteorology in Britain is virtually a monopoly of the Meteorological Office, a sub-department within the Air Ministry, and the Meteorological Research Committce has been continuously effective in bringing the advice of leading university workers, in meteorology and relatod fields, to bear on the rescarch activity of the Office. During these yoars, under the successive chairmanships of Profs. Sydney Chapman, G. M. B. Dobson, Sir David Brunt, Sir Charles Normand and Prof. P. A. Sheppard, the Committee has seen research in the Meteorological Office develop from a fringe activity into a full directorate employing some sixty staff in the scientific officer class alone. Well-known pioneering rosearch includes that of the Meteorological Research Flight with its quite uniquo records of data on cloud physics, and on ozono and water vapour, the application of advancod electronic computing to weather forecasting by dynamical calculation, and more recently the preparation of experiments for forthcoming flights of rockets and Earth satellites. In these twenty-one years, meteorological research has come of age and the guidance and oncouragement afforded by the Metoorological Research Committee are appropriately acknowledged in the November 1962 number of the Meteorological Magazine with historical surveys and accounts of present work.

\section{The Registrar General's Quarterly Return for England and Wales}

Is the second quarter of 1962 the birth-rate con. tinuod to run at the high level of $18 \cdot 8$, comparod with 18.0 in the second quarter of 1961. But, whereas the birth-rate for the second quarter is normally higher than in the first, in 1962 it dropped by 0.6 per thousand, but it is still likely that the total number of births in 1962 will be approximatoly 850,000. Deaths in the second quarter continued at the same level as in previous years, as did infant mortality. The Registrar General's Quarterly Return, which contains these data, also includes an abridged life table for 195961 , showing a life expectancy at birth of 68.1 yoars for males, and 73.9 for females; and a median length of life of about 73 yoars for males and 77 years for femalos (The Registrar General's Quarterly Return for England and Wales-Births, Deaths and Marriages; Infectious Diseases; Weather; Population Estimates; quarter onded 30th June, 1962. No. 454, 2nd Quarter 1962. Pp. 24. London: H.M.S.O., 1962. 2s. 6d. net). Another table shows that cancer and accidents are now responsible for the largest number of yoars of life lost by tho male working population: 115 and 98 per 10,000 population respectively.

\section{The Geological Survey of Great Britain}

THE Summary of Progress of the Keological Survey of Great Britain and the Museum of Practical Geology for the Year 1961 reports continued progress in various field surveys and records that rather less than ono- quarter of Great Britain has not yet been mupped on the 6-in. scale (Pp. iii + 83. London: H.M.S.O., 1962. $5 s .6 d$. net). In addition to this primary survey work. several other areas are being re-surveyed. The main part of this Summary of Progress deals with the usual reports of the geologists working in the various districts. Also included are the sectional reports covering palæontology, petrology, chemical and spectrographic oxamination, water, geophysical and atomic energy discussions. In the Museum, normal curatorial work has proceeded, and advantage is taken to illustrate topical subjects. A display illustrating Tristan da Cunha was on exhibition a few days after the volcanic eruption.

\section{The Soil Survey of Great Britain}

Report No. 14 of the Soil Survey of Great Britain describes now areas surveyed in 1961 amounting to about 2,100 square miles (Pp. viii +46 . London: H.M.S.O., 1962. 5s. net). Reconnaissance surveys in several counties of England and Wales were continued and detailed surveys of the Nuffield Farm Project in the Teign valley of Devonshire and of the lowland mosses of Lancashire were completed. The latter enabled the Agricultural Land Service to prepare land utilization maps of this area. In Scotland mapping is procceding satisfactorily and much of the agricultural lowland is now covored. In addition to the routine work, surveys were undertaken for special purposes, and othor work included exporiments on the influence of added nitrogen on the increase of organic matter and the dovolopment of a biological nitrogen-cycle on an initially inert material. The report includes a map showing the districts where work is proceeding.

\section{Soils and Fertilizers}

THE October issue of Soils and F'ertilizers follows the usual pattern of abstracts, summaries of research reports, a list of bibliographies, two book reviews and a review article. One reviow is of a symposium on "Nitrogen in the Tropics with Particular Roference to Pastures", hold in Brisbane in 1960 and published as Bulletin 46 of the Commonwealth Bureuu of Pastures and Field Crops; the other is on "Sol. Microflore et Végétation: équilibres biochimiques et concurrence biologique", by B. Boullard and $P$. Moreau. The review article is by B. W. Avery, of the Soil Survoy of England and Wales, on "Soil Type and Crop Performance". This is a topie that is assuming great importance with progress in the classification and mapping of soils on one hand and the accumulation of experimental evidence of soil fertility on the other. 'The productive capacity of a soil depends on the interaction of a great many factors coming under such headings as olimatie conditions, management and the more permanent characteristics of the soil, and numerous workers in countries of north-wost Europe and in the Uniterl States have analysed combinations of these factors in attempts to make yield predictions. This is obviously of particular importanec in the selection of suitable sites for horticultural crops and perennial crops such as fruit trees. Since it is clearly out of the question to have long-term field experiments on all the thousands of different soil types, it is essential to decide what criteria in classification are of most significance in the soil-plant relationship and to classify soils so that the soil map may be reliably used in a wide application of the results of fortility studies. 